\title{
PCl-24781 (abexinostat), a novel histone deacetylase inhibitor, induces reactive oxygen species-dependent apoptosis and is synergistic with bortezomib in neuroblastoma
}

\author{
Giselle Saulnier Sholler" ${ }^{*}$, Erika A. Currier ${ }^{2}$, Akshita Dutta ${ }^{1}$, Marni A. Slavik ${ }^{3}$, Sharon A. Illenye ${ }^{4}$, Maria Cecilia F. Mendonca ${ }^{5}$, Julie Dragon ${ }^{3}$, \\ Stephen S. Roberts ${ }^{6}$ and Jeffrey P. Bond ${ }^{3}$ \\ *Correspondence: Giselle.SaulnierSholler@helendevoschildrens.org \\ 'Department of Pediatrics, Helen DeVos Children's Hospital, Michigan State University, College of Human Medicine Grand Rapids, MI, \\ USA. \\ ${ }^{2}$ Department of Pediatrics, Vermont Cancer Center, University of Vermont College of Medicine, Burlington, VT, USA. \\ ${ }^{3}$ Microbiology and Molecular Genetics, University of Vermont College of Medicine, Burlington, VT, USA. \\ ${ }^{4}$ Department of Research and Development, Haemtologic Technologies Inc., Essex Junction, VT, USA. \\ ${ }^{5}$ Department of Pediatrics, Uniformed Services University of the Health Sciences, Bethesda, MD, USA. \\ ${ }^{6}$ Department of Pediatrics Neuroblastoma Program, Memorial Sloan-Kettering Cancer Center, New York, NY, USA.
}

\begin{abstract}
In this study, we investigated the cytotoxic effects of a broad-spectrumhistone deacetylase(HDAC) inhibitor, PCI-24781, alone and in combination with the proteasome inhibitor bortezomib in neuroblastoma cell lines. The combination was shown to induce synergistic cytotoxity involving the formation of reactive oxygen species. The cleavage of caspase-3 and PARP, as determined by western blotting, indicated that cell death was primarily due to apoptosis. Xenograft mouse models indicatedincreased survival among animalstreated with this combination. The Notch signaling pathway and MYCN gene expression were quantified by reverse transcription-polymerase chain reaction (PCR) in cells treated with PCI-24781 and bortezomib, alone and in combination. Notch pathway expression increased in response to an HDAC inhibitor. NFKB1and MYCN were both significantly down regulated. Our results suggest that PCI-24781 and bortezomib are synergistic in neuroblastoma cell lines and may be a new therapeutic strategy for this disease.
\end{abstract}

Keywords: Neuroblastoma, apoptosis, PCI-24781 (abexinostat), bortezomib, ROS

\section{Introduction}

Neuroblastoma (NB) is the most common extracranial solid tumor in childhood, accounting for $12 \%$ of pediatric cancer fatalities annually in the United States [1]. Despite advances in therapy, cure rates for Stage 4 high-risk neuroblastoma continue to be poor, with a five-year survival rate of only $30-40 \%$ in spite of intensive multimodality treatment [2]. To date, no effective therapies exist for relapsed high-risk neuroblastoma,which remains uniformly fatal. The majority of cases of high risk neuroblastoma are initially sensitive to chemotherapy, but upon relapse they are inevitably highly chemoresistant $[2,3]$. Novel treatments are therefore urgently needed [3].

Epigenetic regulation of gene transcription via histone deacetylation is an important mechanism in cellular homeostasis and has been implicated in tumorigenesis. Specifically, acetylation of the e-amino group of lysine residues within the histone proteins maintains an open, transcriptionally active chromatin configuration [4,5]. Histone deacetylases (HDACs) are a family of enzymes that remove these acetyl residues, allowing chromatin folding and resulting in inhibition of transcription. Additionally, HDACs have been found to modify the lysine residues of impor- tant non-histone proteins, including tumor suppressor p53 [6]. Recent studies have shown that disruption of acetylationdeacetylation homeostasis may lead to the silencing of tumor suppressor pathways and may contribute to the development and progression of numerous malignancies [6-8].

HDAC inhibitors are a diverse class of compounds targeting those proteins that modulate transcription by removing acetyl groups from lysine residues in the histone tails of chromatin and by deacetylation of non-histone proteins. These compounds are actively being studied in numerous cancers [8-12]. A potentially important effect of HDAC inhibitors is their induction of reactive oxygen species (ROS) including superoxide, leading to increased oxidative stress and apoptosis [13-16]. HDAC inhibition produces growth inhibitory effects in NB cell lines in vitro $[\mathbf{1 7}, \mathbf{1 8}]$. First-generation HDAC inhibitors have had some clinical success to date, most notably vorinostat (suberoylanilide hydroxamic acid [SAHA]), which is approved by the FDA for use in cutaneous T-cell lymphoma [19]. A phase I study of vorinostat with or without 13-cis-retinoic acid in refractory pediatric cancers (including NB) was recently completed and showed that SAHA was well-tolerated in children, the subset 
analysis for NB for safety was not reported [20]. Despite their promise as novel anti-cancer agents, many first-generation HDAC inhibitors, including SAHA, have suffered from nonoptimal pharmacokinetics and dosage regimens, leading to poor tolerance at therapeutic drug concentrations. This has led to a substantial effort to identify new, second-generation HDAC inhibitors having greater potency and specificity [21].

$\mathrm{PCl}-24781$ (abexinostat; Pharmacyclics, Inc.) is a novel, second-generation phenyl hydroxamic acid-based, orally bioavailable HDAC inhibitor that has previously been shown to have activity in vitro and in vivo against a broad array of cancers, including hematopoietic malignancies and bone and soft-tissue sarcomas [13,22-24]. It has also shown good tolerability and activity in Phase I and II clinical trials against lymphoma, as well as against solid tumors in Phase-I trials [25]. Additionally, it acts as a potent radiosensitizing agent [26] and is synergistic with cytotoxic chemotherapy, such as doxorubicin [27] in preclinical models.

Bortezomib is a proteasome inhibitor currently used for first-line therapy of multiple myeloma and in relapsed mantle cell lymphoma [28]. In both of these tumors, increased generation of ROS has been associated with cell death [29-31]. Bortezomib was shown to induce apoptosis of NB cells as a single agent both in vitro and in vivo $[32,33]$.

Recently, Bhalla et al., showed that the combination of $\mathrm{PCl}-24781$ plus bortezomib was synergistic and induced ROSdependent apoptosis in Hodgkin and non-Hodgkin lymphoma cells [13]. To our knowledge, however, there have been no reports of combining proteasome and HDAC in hibitors in NB. In this study, we show that the potent HDAC inhibitor $\mathrm{PCl}-24781$ is both cytotoxic to NB cells as a single agent at nanomolar concentrations and is synergistic in vitro and in vivo with the proteasome inhibitor bortezomib. We also show that this combination therapy induces apoptosis, up-regulates Notch pathway signaling, and inhibits MYCN expression. These effects are abrogated by pretreatment with the antioxidant $\mathrm{N}$-acetylcysteine, suggesting that ROS-mediated apoptosis induction may bea major mechanism of action.

\section{Methods}

\section{Human neuroblastoma cell lines}

The following NB cell lines were used in all experiments: SMSKCNR, SKNBE(2)C, LA1-55n, and LAN2. The SMS-KCNR cell line was obtained from the lab of Dr. John Maris (Children's Hospital of Philadelphia, Philadelphia, PA). SKNBE(2)C, LA1-55n, and LAN2 cell lines were a gift from the labs of Drs. Robert Ross and Barbara Spengler (Fordham University, Bronx NY). All cell lines were authenticated using the Short Tandem Repeat method by the DNA Diagnostics Center (Fairfield, $\mathrm{OH}$ ). All cell lines were cultured at $37^{\circ} \mathrm{C}$ under humidified atmospheric oxygen and $5 \% \mathrm{CO}_{2}$ in RPMI 1640 (Mediatech, Manassas, VA) supplemented with $10 \%$ (v/v) FBS (Invitrogen, Carlsbad, CA), 100 units $/ \mathrm{mL}$ penicillin, and $100 \mu \mathrm{g} / \mathrm{mL}$ streptomycin (Mediatech) as previously described [34-36].

\section{Drugs and antibodies}

The second-generation HDAC inhibitor $\mathrm{PCl}-24781$ was provided by Pharmacyclics, Inc. (Sunnyvale, CA). Bortezomib and the HDAC inhibitor suberoylanilidehydroxamic acid (SAHA/ vorinostat) were obtained from LC Laboratories (Woburn, MA). Sodium butyrate and valproic acid were from Sigma Aldrich (St. Louis, MO). Rabbit-anti-human cleaved-caspase- 3 and mouse-anti-human PARP antibodies were purchased from Cell Signaling Technology (Danvers, MA).

\section{Cell viability assays}

Neuroblastoma cell lines were treated with various concentrations of bortezomib and PCI-24781(1-1000nM) alone or in combination for $48 \mathrm{~h}$. Cells were also treated with the HDAC inhibitors SAHA, sodium butyrate, and valproic acid. Cell viability was assessed using Calcein AM (AnaSpec, Freemont, CA). IC $C_{50}$ values for each compound or combination were calculated using Prism 5 software (GraphPad Inc., La Jolla, CA). Cell viability assays were repeated in the presence of $15 \mathrm{mMN}$-acetyl-L-cysteine (Sigma Aldrich, St. Louis, MO).

Measurements of fractional survival, $S$, at concentrations of bortezomib $b$, and $\mathrm{PCl}-24781 p$, were interpreted with the aid of the models $=\exp \left(\beta_{10} b+\beta_{01} p+\beta_{20} b^{2}+\beta_{02} p^{2}+\beta_{11} b p\right)+$ $\varepsilon$, where $\beta$ is the vector of model parameters and $\varepsilon$ is the random error. Model parameters were estimated using the R software program (www.R-project.org).

\section{Western blotting}

Cells were treated for $48 \mathrm{~h}$ with HDAC inhibitors and/or bortezomib in 100-mm plates. Cells were collected by scraping, protein was extracted, and electrophoresis performed on a $15 \%$ SDS-polyacrylamide gel and blotted onto polyvinylidene fluoride (PVDF) membranes. The blots were probed with rabbit anti-human antibody to cleaved caspase 3 and $\beta$-actin, as well as mouse anti-human PARP antibody. Protein bands were visualized using infrared dye-conjugated anti-rabbit secondary antibodies (LI-COR Biosciences, Lincoln, NE) and photographed using an Odyssey Infrared Imaging System (LI-COR Biosciences).

\section{mRNA preparation and gene expression profiling}

SMS-KCNR cells were treated in duplicate with $4 \mathrm{nM}$ bortezomib, $125 \mathrm{nM} \mathrm{PCl}-24781$, or the combination for $24 \mathrm{~h}$. RNA was extracted using the RNeasy micro kit (Qiagen, Valencia, CA) following the manufacturer's instructions and eluted in Riboblock RNase inhibitor (Formentas). RNA quality was verified with all calculated RIN scores above 9 (Quality control pass is RIN >6.5). Five micrograms of RNA per array was subsequently hybridized to Affymetrix GeneChip Human U133 Plus 2.0 arrays per the manufacturer's protocols. Arrays were analyzed by the Vermont Genetics Network Microarray Facility using Affymetrix GCOS software, according to the manufacturer's instructions. All other calculations were performed using R/ BioConductor tools available from http://www.R-project.org. 
Probe set by sample matrix expression statistics were calculated using the Robust Multichip Average method $[37,38]$. Quality statistics were calculated using the Simpleaffy and affyQCReport packages [39].

\section{Quantitative RT-PCR}

Notch pathway and MYCN gene expression levels were measured using an Applied Biosystems 7500 Real-Time PCR system (Applied Biosystems, Foster City, CA) using dual-labeled fluorescent probes, with TaqMan One-Step RT-PCR Master Mix reagents (Applied Biosystems). Briefly, 50 or $100 \mathrm{ng}$ of mRNA per reaction was used. Reaction conditions were $48^{\circ} \mathrm{C}$ for $30 \mathrm{~min}, 95^{\circ} \mathrm{C}$ for $10 \mathrm{~min}$, followed by $95^{\circ} \mathrm{C}$ for $15 \mathrm{~s}$ and $60^{\circ} \mathrm{C}$ for $1 \mathrm{~min}$, for a total of 40 cycles. Gene expression for NOTCH1-4, JAG1 and 2, HES1, and MYCN was measured using TaqMan Assay-on-Demand predesigned probe sets (Applied Biosystems). The expression level of $18 \mathrm{~S}$ ribosomal RNA was used as an endogenous control to normalize expression results, and fold changes between samples were calculated using the $2^{-\Delta \Delta C t}$ method according to the manufacturer's instructions. Statistical analysis was performed using InStat Software (Graphpad).

\section{In vivo assays}

The Animal Care and Use Committee at the University of Vermont approved all animal studies. Six-week-old female nude mice (NCRNU-F, CrTac:NCr-Foxn $1^{\text {nu}}$ ) (Taconic Farms, Germantown, NY) were injected with $8 \times 10^{6}$ SMS-KCNR cells suspended in $0.2 \mathrm{~mL}$ of Matrigel subcutaneously into the left flank. Beginning $10 \mathrm{~d}$ post-injection, 6 mice per group were treated with daily intraperitoneal doses of vehicle control, $0.5 \mathrm{mg} / \mathrm{kg}$ bortezomib, $12.5 \mathrm{mg} / \mathrm{kg} \mathrm{PCl}-24781$, or a combination of bortezomib plus $\mathrm{PCl}-27481$ at 0.5 and 12.5 $\mathrm{mg} / \mathrm{kg}$, respectively. Tumors were measured twice weekly and tumor volume was calculated using the ellipsoid formula [length $\mathrm{x}$ width $\mathrm{x}$ height $\mathrm{x}$ 0.52]. Treatment was continued until tumors exceeded $3.0 \mathrm{~cm}^{3}$, at which point the mice were euthanized. Tumors were collected and weighed. The experiment was performed in duplicate.

\section{Results}

PCI-24781 and bortezomib exhibited single-agent cytotoxicity against $\mathrm{NB}$ cell lines

Four neuroblastoma cell lines SKNBE(2)C, SMS-KCNR, LA1$55 n$, and LAN2, were treated with various concentrations of four different HDAC inhibitors. Three of the inhibitors were first-generation drugs being tested in neuroblastoma clinical studies (SAHA, sodium butyrate, and valproic acid), and the fourth was the second-generation HDAC inhibitor PCl-24781 (Figure 1a). $\mathrm{PCl}-24781$ exhibited the greatest cytotoxicity against the NB cell lines, with $\mathrm{IC}_{50}$ values ranging from $83.5 \mathrm{nM}$ for SMS-KCNR to $196.4 \mathrm{nM}$ for SKNBE(2)C. The $\mathrm{IC}_{50}$ values for the other HDAC inhibitors were for SAHA, 5.8-123.3 mM; for sodium butyrate, 3.8-10.4 mM; and for valproic acid, 2.0-17
$\mathrm{mM}$. Bortezomib also exhibited cytotoxicity against the SMSKCNR, LA 1-55n and SKNBE(2)Ccell lines (Figure 1 b). The IC of bortezomib for these cell lines was estimated to be $2.4 \mathrm{nM}$ for SMS-KCNR, 3.6nM for LA1-55n, and 3.5nM for SKNBE(2)C, but $6.31 \mathrm{nM}$ for LAN2 cells.

\section{PCI-24781 and bortezomib are synergistic}

SMS-KNCR, LA1-55n, SKNBE(2)C, and LAN2 NB cell lines were treated with the combination of $\mathrm{PCl}-24781$ plusbortezomib at various concentrations. Plots of cell survival as a function of the drug concentrations suggested that the two drugs act additively or synergistically over a wide rangeof concentrations. The contours of cell survival (solid lines) appear either straight or convex. Parameter estimation suggests synergism $(p=0.01)$. Closer inspection of one region of the $\mathrm{PCl}-24781$ /bortezomib dose plane with the LA1-55n cell line (Figure 1c) supports this conclusion. Consistent with synergism, $\mathrm{PCl}-24781$ alone at up to $60 \mathrm{nM}$ has no observable effect on survival, while it has a clear effect in the presence of $5 \mathrm{nM}$ bortezomib.

\section{PCI-24781 and bortezomib induced caspase-3-mediated apoptosis in NB cell lines}

Treatment of neuroblastoma cell lines (SMS-KCNR and LA1$55 \mathrm{n}$ ) with $\mathrm{PCl}-24781$ and bortezomib agents led to induction of apoptosis as measured by the presence of cleaved PARP and of cleaved caspase- 3 by western blotting (Figure 2). The amount of cleaved caspase-3 was greater after treatment with the combination of agents than with either agent alone.

\section{$\mathrm{N}$-acetyl-cysteine pretreatment blocked cytotoxicity of PCI-24781 and bortezomib}

$\mathrm{PCl}-24781$ induces the formation of reactive oxygen species in neuroblastoma cells. To confirm that the effect of these drugs involved the formation of ROS, cells were pretreated with the antioxidant $\mathrm{N}$-acetyl-cysteine (NAC). Cells were thentreated with either PCl-24781 (100nM), bortezomib $(6 \mathrm{nM})$, or both. In the absence of NAC, a decrease in cell viability was seen for the combination relative to the single agents (Figure 3). With $15 \mathrm{mMNAC}$ pretreatment, the cytotoxicity of the combination was greatly decreased, indicating that the cytotoxicity induced by these agents involves ROS generation $(p<0.005$ based on 9 experiments representing a range of $\mathrm{PCl}-24781$ and bortezomib concentrations, data not shown).

\section{PCI-24781 and bortezomib up-regulated NOTCH} pathway genes and suppressedMYCN

SMS-KCNR cells were treated with PCl-24781 (125nM), bortezomib (4nM), or the combination. After2 $4 \mathrm{~h}$ of treatment, microarray analysis revealed significant up-regulation of multiple various Notch signaling pathway genes (Table 1). The gene table was constructed using primary literature and Gene Ontology (www.geneontology.org) for notch signaling, oxidative stress and apoptosis. Genes differentially expressed between combination and control 
Sholler et al. Journal of Cancer Therapeutics \& Research 2013,

http://www.hoajonline.com/journals/pdf/2049-7962-2-21.pdf

doi: 10.7243/2049-7962-2-21

$1 \mathrm{a}$
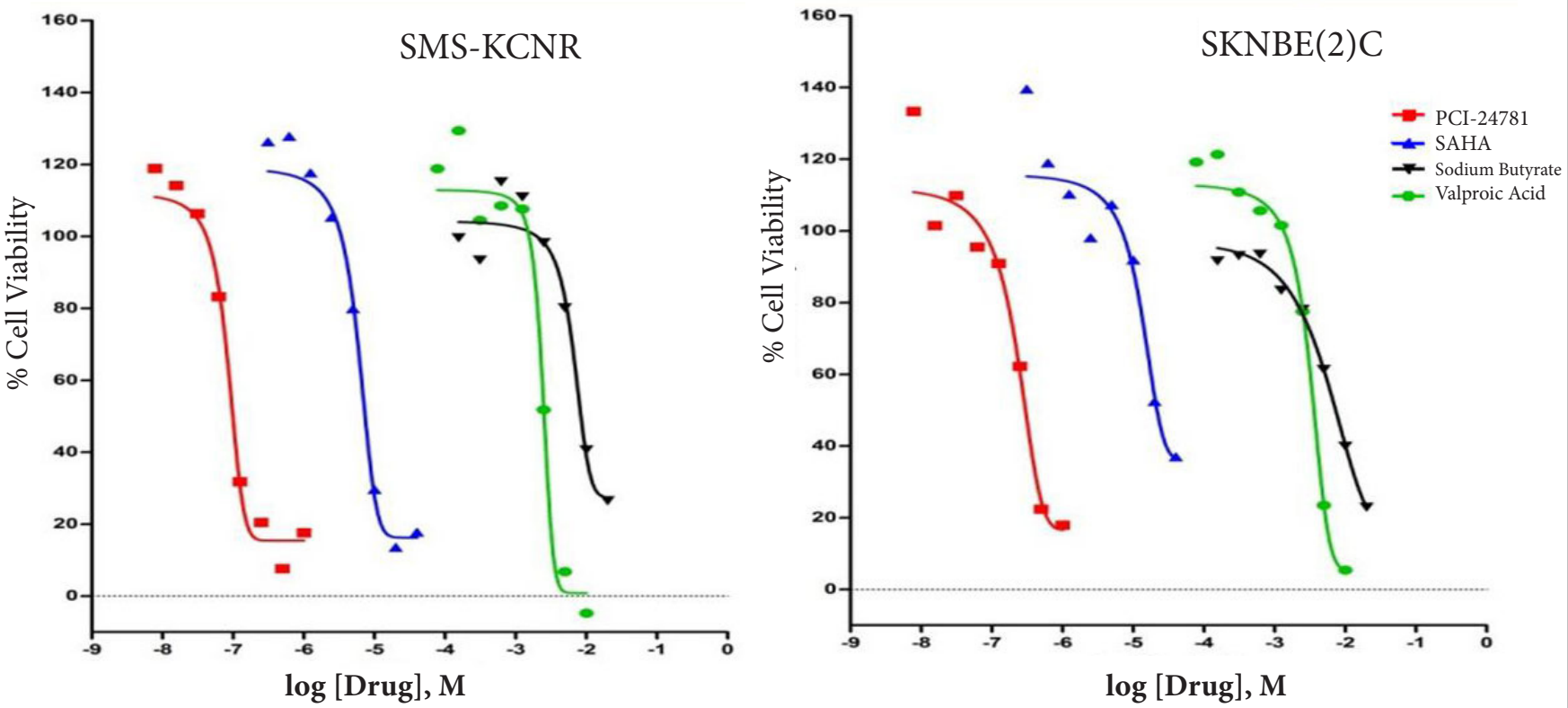

\begin{tabular}{|l|l|l|}
\hline Drug & IC $_{50}$ & F.P. \\
\hline PCI-24781 & $83.5 \mathrm{nM}$ & - \\
\hline SAHA & $5.83 \mathrm{uM}$ & $-70 \mathrm{X}$ \\
\hline Sodium Butyrate & $6.62 \mathrm{mM}$ & $-79,281 \mathrm{X}$ \\
\hline Valproic Acid & $2.42 \mathrm{mM}$ & $-28,982 \mathrm{X}$ \\
\hline
\end{tabular}

\begin{tabular}{|l|l|l|}
\hline Drug & IC $_{50}$ & F.P. \\
\hline PCI-24781 & $196.4 \mathrm{nM}$ & - \\
\hline SAHA & $12.3 \mathrm{uM}$ & $-63 \mathrm{X}$ \\
\hline Sodium Butyrate & $10.4 \mathrm{mM}$ & $-52,953 \mathrm{X}$ \\
\hline Valproic Acid & $3.1 \mathrm{mM}$ & $-15,748 \mathrm{X}$ \\
\hline
\end{tabular}
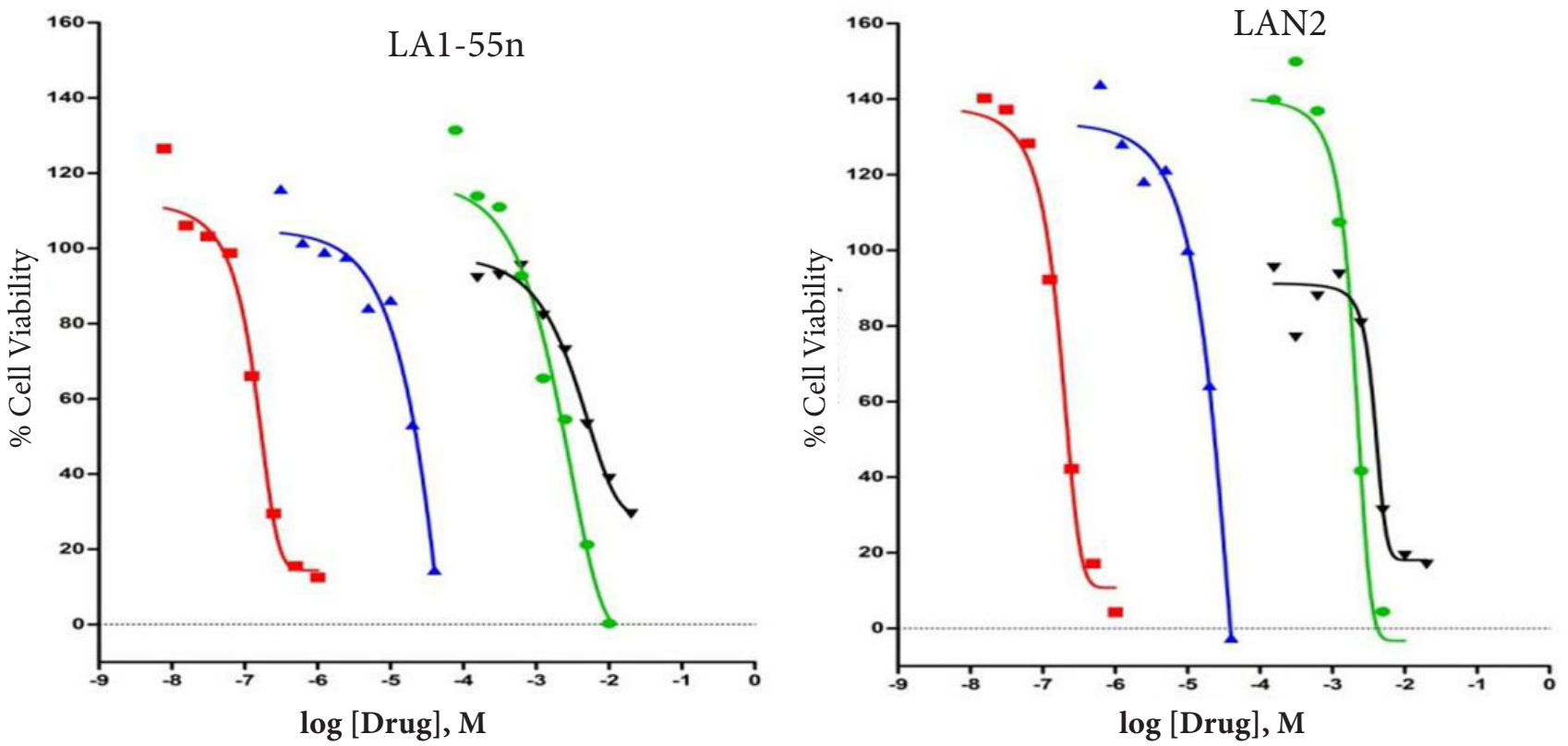

\begin{tabular}{|l|l|l|}
\hline Drug & IC $_{50}$ & F.P. \\
\hline PCI-24781 & $122.6 \mathrm{nM}$ & - \\
\hline SAHA & $123.3 \mathrm{uM}$ & $-1,006 \mathrm{X}$ \\
\hline Sodium Butyrate & $5.3 \mathrm{mM}$ & $-43,230 \mathrm{X}$ \\
\hline Valproic Acid & $17.4 \mathrm{mM}$ & $-141,925 \mathrm{X}$ \\
\hline
\end{tabular}

\begin{tabular}{|l|l|l|}
\hline Drug & IC $_{50}$ & F.P. \\
\hline PCI-24781 & $163.1 \mathrm{nM}$ & - \\
\hline SAHA & $18.4 \mathrm{uM}$ & $-113 \mathrm{X}$ \\
\hline Sodium Butyrate & $3.8 \mathrm{mM}$ & $-23,200 \mathrm{X}$ \\
\hline Valproic Acid & $2.0 \mathrm{mM}$ & $-12,262 \mathrm{X}$ \\
\hline
\end{tabular}

4 
Continuation of Figure 1.

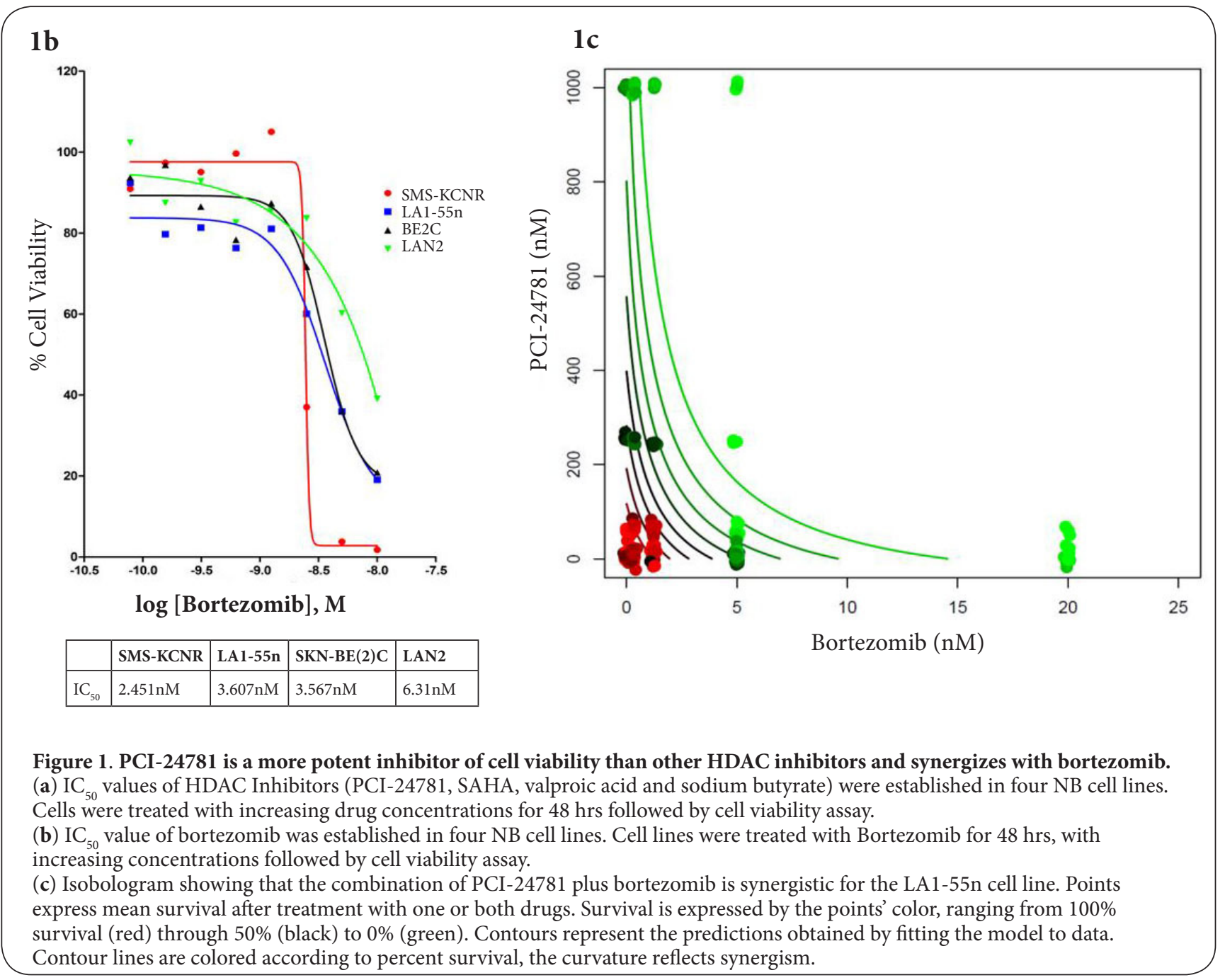

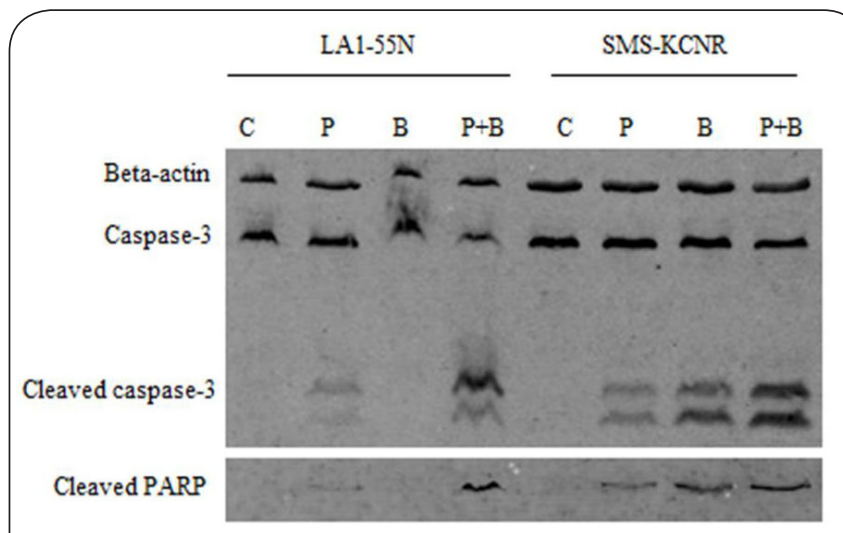

Figure 2. Treatment with PCI-24781 and bortezomib result in caspase mediated apoptosis in neuroblastoma.

Cells were incubated with vehicle (C), $1 \mu \mathrm{M}$ PCI-24781 (P), 10 mMbortezomib (B), or the combination $(\mathrm{P}+\mathrm{B})$ for $48 \mathrm{hrs}$ and cell lysates were collected and run on western blots to evaluate for cleaved caspase 3 and PARP. sample groups were identified based on at least 1.2 fold-change (in either direction) and adjusted p-value < 0.05 (Figure 4a, Table 1). Treatment with $\mathrm{PCl}-24781$ alone resulted in up-regulation of $J A G 1$ at $6 \mathrm{~h}$ and up-regulation of NOTCH2 at $24 \mathrm{~h}$. These findings were confirmedusing independent biological replicates by real-time qPCR (Figure $4 \mathbf{b}$ ). Of importance in neuroblastoma, MYCN was suppressed with either bortezomib or $\mathrm{PCl}-24781$ as well as with the combination at $24 \mathrm{~h}$ relative to controls.

\section{PCI-24781 and bortezomib in combination increased survival in a mouse xenograft models}

Nude [nu/nu] mice $(n=6)$ were injected with SMS-KCNR cells subcutaneously in the left flank. Once the tumors were palpable, the mice were treated once daily with vehicle, 0.5 $\mathrm{mg} / \mathrm{kg}$ bortezomib, $12.5 \mathrm{mg} / \mathrm{kg} \mathrm{PCl}-24781$, or a combination of both. The tumors were measured twice weekly. Mice were euthanized when a maximum tumor size of $3 \mathrm{~cm}^{3}$ was reached. 
Sholler et al. Journal of Cancer Therapeutics \& Research 2013,

http://www.hoajonline.com/journals/pdf/2049-7962-2-21.pdf

doi: $10.7243 / 2049-7962-2-21$

Table 1. Genes of SMS-KCNR cells in five categories differentially expressed upon 24-h treatment with PCI-24781, bortezomib and both.

\begin{tabular}{|c|c|c|c|c|c|c|c|}
\hline \multicolumn{8}{|c|}{ Genes of SMS-KCNR cells differentially expressed upon 24-h treatment with PCI-24781, bortezomib, and both. } \\
\hline & & \multicolumn{2}{|c|}{ PBmC } & \multicolumn{2}{|c|}{$\mathrm{PmC}$} & \multicolumn{2}{|c|}{$\mathrm{BmC}$} \\
\hline Accn \# & Gene Title/Gene Symbol & F.C. & P-value & F.C. & P-value & F.C. & P-value \\
\hline \multicolumn{8}{|c|}{ Notch Signaling Pathway } \\
\hline NM_004316 & Achaete-scute complex homolog 1 (ASCL1) & -3.002 & 0.000927 & -3.86901 & 0.00017 & -2.19856 & 0.231699 \\
\hline NM_000389 & Cyclin-dependent kinase inhibitor 1A (CDKN1A) & -2.60325 & 0.002993 & -2.71053 & $1.31 \mathrm{E}-05$ & -1.39463 & 0.478301 \\
\hline NM_005618 & Delta-like $1(D L L 1)$ & 3.033902 & 0.024784 & 2.877812 & 0.002491 & 1.256778 & 0.790808 \\
\hline NM_005524 & Hairy and enhancer of split 1 (HES1) & 2.205546 & 0.001785 & 2.215463 & $2.96 \mathrm{E}-05$ & 1.076456 & 0.895074 \\
\hline NM_012259 & Hairy/enhancer-of-split related with YRPW motif 2 (HEY2) & 1.394142 & 0.081298 & 1.391811 & 0.010457 & -1.01637 & 0.998356 \\
\hline NM_000214 & Jagged 1 (JAG1) & 3.358865 & 0.030276 & 4.389256 & 0.000372 & 1.447692 & 0.329478 \\
\hline NM_002226 & Jagged 2 (JAG2) & 1.297184 & 0.264245 & 1.34398 & 0.062734 & -1.01957 & 0.958371 \\
\hline NM_002228 & Jun proto-oncogene (JUN) & -1.40705 & 0.027099 & -1.52671 & 0.259297 & -1.22093 & 0.564432 \\
\hline NM_032427 & Mastermind-like 2 (MAML2) & 2.191402 & 0.005553 & 2.132724 & 0.000279 & 1.070269 & 0.964675 \\
\hline NM_001200001 & Notch-2 (NOTCH2) & 47.35651 & $7.20 \mathrm{E}-05$ & 59.36702 & $2.44 \mathrm{E}-06$ & 2.488318 & 0.231699 \\
\hline NM_000435 & Notch-3 (NOTCH3) & 1.720812 & 0.006448 & 1.669143 & 0.00024 & -1.00333 & 1.000000 \\
\hline NM_004557 & Notch-4 (NOTCH4) & -2.71993 & 0.000887 & -3.27107 & 0.000323 & -1.69939 & 0.231699 \\
\hline NM_005378 & V-mycmyelocytomatosis viral related oncogene (MYCN) & -1.27879 & 0.026751 & -1.21634 & 0.017491 & -1.18255 & 0.677238 \\
\hline \multicolumn{8}{|c|}{ Oxidative Stress Response } \\
\hline NM_001719 & Bone morphogenetic protein 7 (BMP7) & 15.579 & 0.0012 & 12.9433 & $1.17 \mathrm{E}-06$ & 1.6101 & 0.2891 \\
\hline NM_000088 & Collagen type 1 , alpha $1(C O L 1 A 1)$ & 5.200 & 0.0018 & 4.8706 & 0.0001 & 1.2563 & 0.5705 \\
\hline NM_005794 & Dehydrogenase/reductase (SDR family) member 2 (DHRS2) & 19.624 & 0.0001 & 17.1225 & $1.42 \mathrm{E}-05$ & 1.7535 & 0.2700 \\
\hline NM_005235 & V-erb-a erythroblastic leukemia viral oncogene homolog 4 (ERBB4) & 21.800 & 0.0002 & 19.8785 & $7.85 \mathrm{E}-07$ & 2.3799 & 0.2502 \\
\hline NM_002084 & Glutathione peroxidase 3 (plasma) (GPX3) & 16.642 & 0.0003 & 16.9895 & $2.13 \mathrm{E}-06$ & 1.6247 & 0.3183 \\
\hline NM_001008397 & Glutathione peroxidase 8 (putative) (GPX8) & 5.060 & 0.0029 & 4.5064 & 0.0001 & 1.2477 & 0.5761 \\
\hline NM_0021333 & Hemeoxygenase (decycling) 1 (HMOX1) & 11.232 & $7.56 \mathrm{E}-05$ & 9.145 & $3.14 \mathrm{E}-05$ & 1.4662 & 0.4852 \\
\hline NM_005931 & MHC class I polypeptide-related sequence B (MICB) & 71.874 & $6.14 \mathrm{E}-05$ & 81.096 & $2.62 \mathrm{E}-07$ & 2.7817 & 0.2316 \\
\hline NM_004994 & $\begin{array}{l}\text { Matrix metallopeptidase } 9 \text { (gelatinase } \mathrm{B}, 92 \mathrm{kDa} \text { gelatinase, } 92 \mathrm{kDa} \text { type IV } \\
\text { collagenase) (MMP9) }\end{array}$ & 5.252 & 0.00202 & 5.198 & 0.0238 & 1.2637 & 0.4267 \\
\hline NM_024420 & Phospholipase A2, group IVA (cytosolic, calcium-dependent) (PLA2G4A) & 7.690 & 0.00081 & 6.700 & 0.0110 & 1.2909 & 0.4072 \\
\hline NM_000962 & $\begin{array}{l}\text { Prostaglandin-endoperoxide synthase } 1 \text { (prostaglandin } \mathrm{G} / \mathrm{H} \text { synthase and } \\
\text { cyclooxygenase) (PTGS1) }\end{array}$ & 12.968 & 0.00016 & 9.145 & $3.14 \mathrm{E}-05$ & 1.4691 & 0.2814 \\
\hline NM_000345 & Synuclein, alpha (non A4 component of amyloid precursor) (SNCA) & 4.230 & 0.0023 & 4.111 & $3.60 \mathrm{E}-05$ & 1.2162 & 0.5611 \\
\hline NM_001178040 & Syntaxin $3(S T X 3)$ & 20.771 & $9.76 \mathrm{E}-05$ & 17.330 & $5.61 \mathrm{E}-06$ & 1.8778 & 0.2998 \\
\hline \multicolumn{8}{|c|}{ Apoptosis and TNFR } \\
\hline NM_001165 & Baculoviral IAP repeat containing 3 (BIRC3) & 6.5821 & 0.000693 & 6.758683 & 0.00138 & 1.4916 & 0.242024 \\
\hline NM_001226 & Caspase 6, apoptosis-related cysteine peptidase (CASP6) & 3.4102 & 0.00104 & 3.208055 & 0.000162 & 1.1764 & 0.739085 \\
\hline NM_015675 & Growth arrest and DNA-damage-inducible, beta (GADD45B) & 5.5125 & 0.002736 & 5.482137 & $2.35 \mathrm{E}-05$ & 1.3944 & 0.391091 \\
\hline NM_000177 & Gelsolin(GSN) & 5.3800 & 0.001 & 5.109392 & $1.85 \mathrm{E}-05$ & 1.5512 & 0.264134 \\
\hline NM_0021333 & Hemeoxygenase (decycling) 1 (HMOX1) & 11.2322 & $7.56 \mathrm{E}-05$ & 11.45708 & $5.12 \mathrm{E}-07$ & 1.7320 & 0.277403 \\
\hline NM_000594 & Tumor necrosis factor (TNF) & 7.3495 & 0.000347 & 6.408024 & $8.56 \mathrm{E}-06$ & 1.8115 & 0.231699 \\
\hline NM_001270507 & Tumor necrosis factor, alpha-induced protein 3 (TNFAIP3) & 2.2634 & 0.005704 & 2.187222 & 0.000655 & 1.4447 & 0.606515 \\
\hline NM_016639 & Tumor necrosis factor receptor superfamily, member 12A (TNFRSF12A) & 2.0183 & 0.007093 & 1.971959 & 0.014324 & 1.3393 & 0.410985 \\
\hline NM_001164155 & Tumor necrosis factor receptor superfamily, member 19 (TNFRSF19) & 6.1248 & 0.000168 & 6.084076 & $9.62 \mathrm{E}-07$ & 1.6015 & 0.295686 \\
\hline NM_001145645 & Tumor necrosis factor (ligand) superfamily, member 13b (TNFSF13B) & 2.2388 & 0.003709 & 1.999324 & 0.00064 & 1.4443 & 0.299862 \\
\hline \multicolumn{8}{|c|}{ Cell Cycle Related } \\
\hline NM_001759 & G1/S specific cyclin D2 (CCND2) & 87.4966 & 0.000182 & 95.4013 & $7.85 \mathrm{E}-07$ & 1.8244 & 0.27847 \\
\hline NM_001258 & Cyclin-dependent kinase-3 (CDK3) & -1.9674 & 0.002626 & -1.5957 & 0.036293 & -1.3050 & 0.354757 \\
\hline \multicolumn{8}{|l|}{ NF-kB Related } \\
\hline NM_001165412 & Nuclear factor of kappa light polypeptide gene enhancer in B-cells 1(NFKB1) & -1.2877 & 0.165361 & -1.1939 & 0.130896 & -1.1483 & 0.612514 \\
\hline NM_025107 & Homo sapiens myc target 1 (MYCT1) & 2.0335 & 0.009183 & 2.2886 & 0.000631 & 1.6837 & 0.297559 \\
\hline NM_000600 & Homo sapiens interleukin 6 (interferon, beta 2) (IL6) & -1.3102 & 0.056794 & -1.3336 & 0.037262 & -1.2640 & 0.382162 \\
\hline NM_001042533 & MYC induced nuclear antigen (MINA) & 1.8988 & 0.015987 & 1.4745 & 0.005057 & 1.6331 & 0.296344 \\
\hline
\end{tabular}

Up-regulated genes are shown as positive fold change values and down-regulated genes are shown as negative fold change values. Treatment conditions include PCI-24781 and bortezomib minus control (PBmC), PCI-24781 minus control (PmC), and bortezomib minus control (BmC). Fold changes (f.c.) indicate sign fold changes, and $\mathrm{p}$ values (p) represent adjusted $\mathrm{p}$ values. 


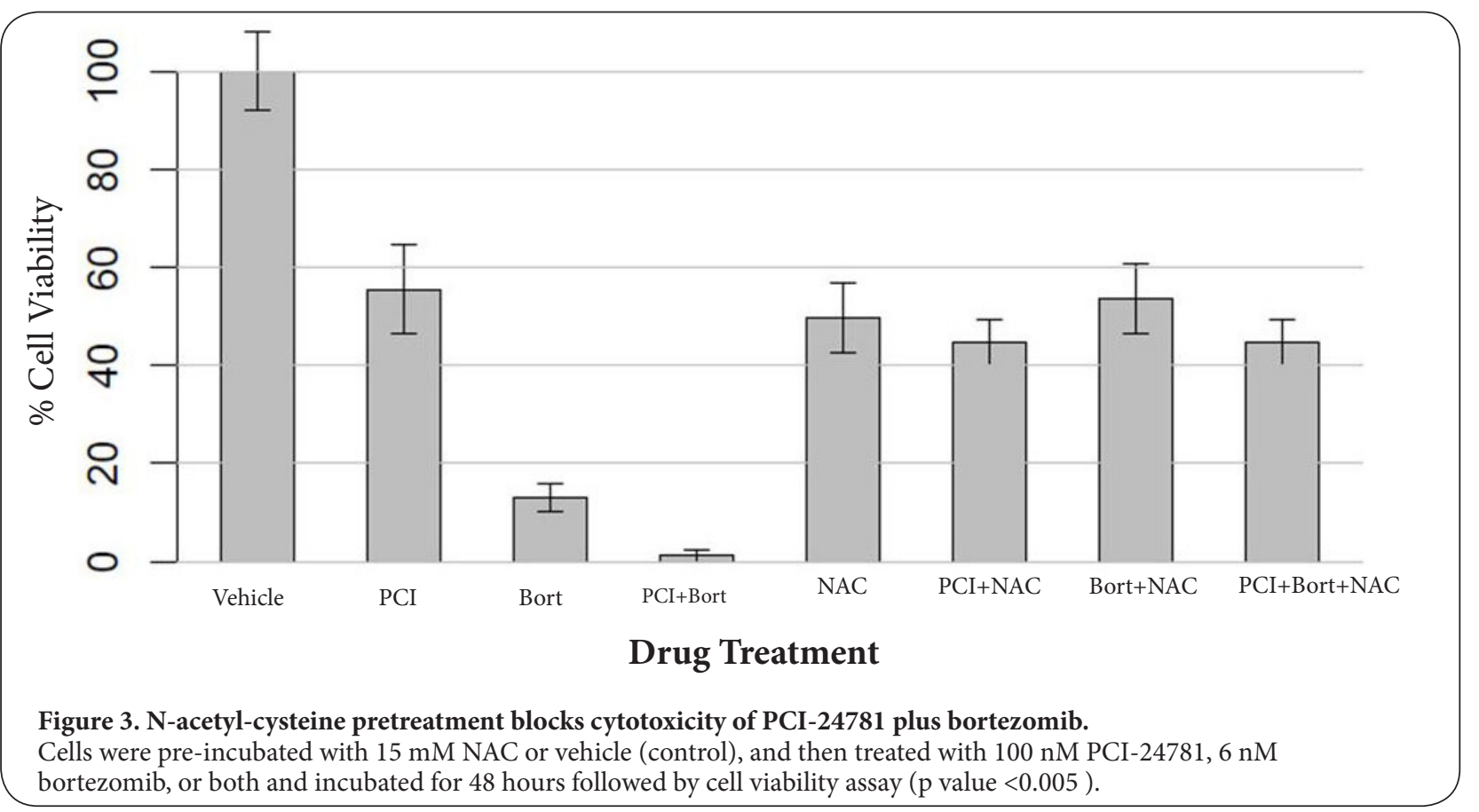

There were no signs of drug-related toxicities as noted by change in body weight or behavior. Neuroblastoma xenograft mice models showed an increase in time to survival from 55 days in the control group to 80 days in mice treated with the $\mathrm{PCl}-24781$ plus bortezomib combination (Figure $5 ; \mathrm{p}=0.001$ ).

\section{Discussion}

In this study, the HDAC inhibitor $\mathrm{PCl}-24781$ had significant activity in vitro and in vivo as a single agent against several NB cell lines. Specifically, PCl-24781 showed dose-dependent cytotoxicity with an $\mathrm{IC}_{50}$ of $<200 \mathrm{nM}$, which is well within previously reported clinically achievable range [40]. This dose range was shown to have no cytotoxic effect on human normal foreskin fibroblast cell line HS-68 [41]. This is in contrast to the other HDAC inhibitors tested (SAHA, sodium butyrate, and valproic acid), which had $\mathrm{IC}_{50}$ values in the micromolar to millimolar ranges. $\mathrm{PCl}-24781$ induced apoptosis in all the NB cell lines tested, as shown by cleavage of caspase- 3 and PARP. This effect was notably increased when combined with bortezomib. While PCl-24781 showed significant single-agent cytotoxicity, its synergy with bortezomib was striking. At doses that caused no effect as single agents, the combination of $\mathrm{PCl}-24781$ plusbortezomib resulted in cell viability of $5 \%$ or less in all the cell lines tested. Treatment of mouse xenografts with this drug combination led to a doubling of mean survival time from 55 to 80 days. Importantly, the animals showed no evidence of systemic toxicity as reported by Bhalla et al., as well [42], suggesting that this combination could be well tolerated in relapsed neuroblastoma patients, all of whom have been heavily pretreated with cytotoxic chemotherapy.
Gene expression profiling of NB cells treated with $\mathrm{PCl}-24781$ plusbortezomib identified significant down-regulation of numerous genes, including MYCN and NFKB1. MYCN is a critically important proto-oncogene in NB, with nearly $1 / 3$ of cases having MYCN amplification and associated poor outcomes [2]. A report by Nawrocki et al., [43] showed that Myc regulates the sensitivity of multiple myeloma cells to bortezomib and SAHA-induced cell death. Interestingly, they found that the sensitivity of multiple myeloma to treatment with the combination of bortezomib and SAHA was increased in patients with overexpression of c-Myc. Our finding that treatment with $\mathrm{PCl}-24781$ significantly down-regulated the expression of this critical neuroblastoma oncogene suggests that $M Y C N$-amplified patients may particularly benefit from this therapy.

The mechanism by which HDAC inhibitors and bortezomib cause cell death remains controversial. Our results suggest that the observed cytotoxicity is ROS-dependent, as the effects of these compounds (especially in combination) were significantly decreased when cells were pretreated with the antioxidant NAC. Both PCl-24781 and bortezomib have been shown independently to cause ROS generation; additionally, $\mathrm{PCl}-24781$ was previously shown to suppress NF$\mathrm{KB}$ expression, a critically important regulator of the cellular oxidative stress response [13]. Our findings confirm these observations. It seems plausible that the combination of these two compounds leads to both increased ROS generation and suppression of important oxidative stress responses, leading to increased apoptosis.

Interestingly, our gene expression studies identified the 
$4 a$

4b

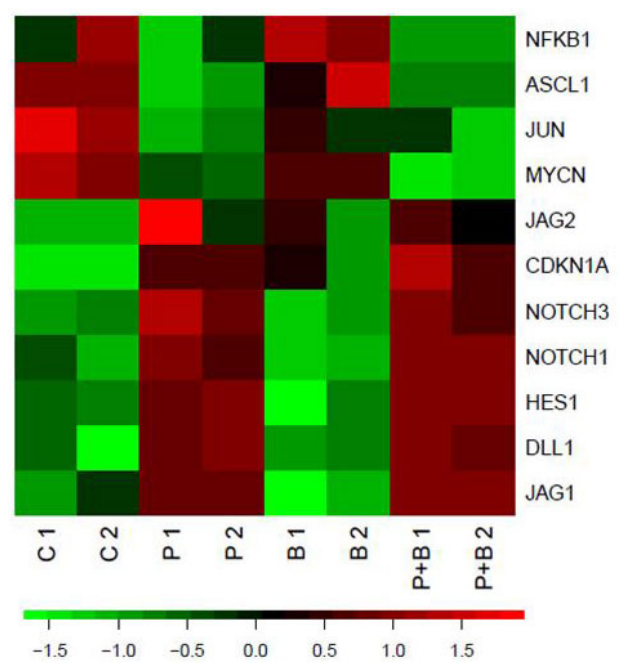

A

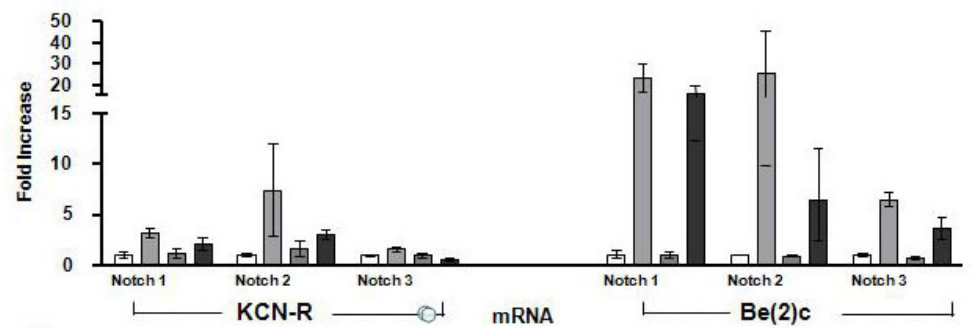

B

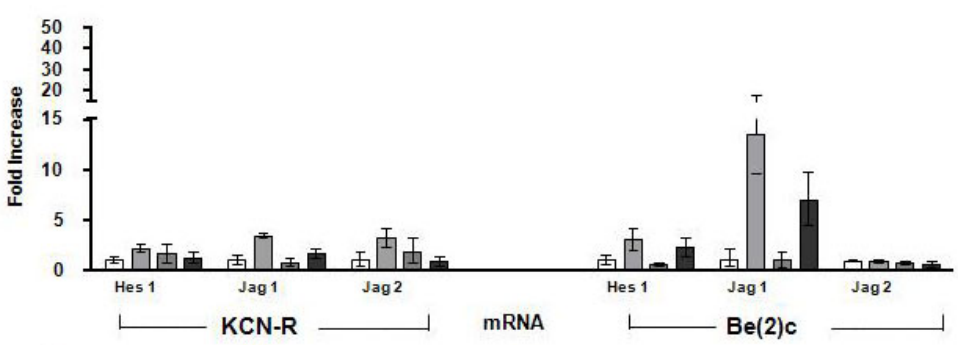

C

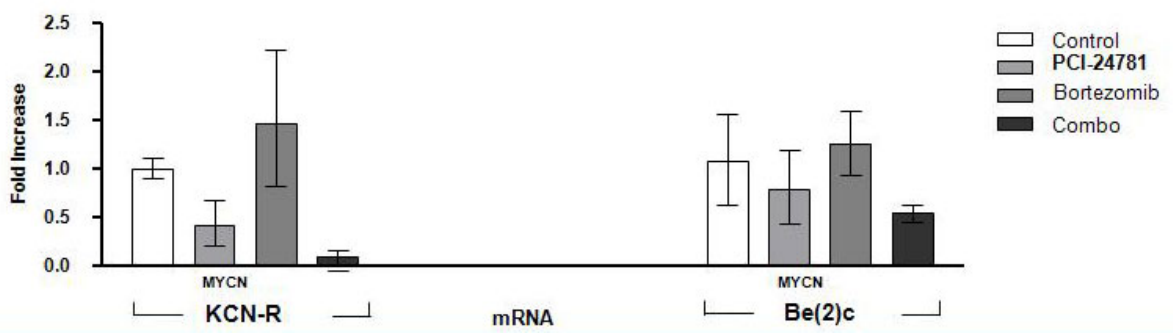

Figure 4. PCI-24781 treatment up-regulates NOTCH pathway genes and suppresses MYCN, as confirmed by RT-PCR. (a) SMS-KCNR cells were treated in duplicate with $4 \mathrm{nM}$ bortezomib, $125 \mathrm{nM}$ PCI-24781, or the combination for $24 \mathrm{~h}$. RNA was isolated and hybridized to Affymetrix U133 2+ arrays. Rows represent genes; columns represent samples. P 1 and P 2 represent replicate PCI-24781 treatments; B 1 and B 2 represent Bortezomib treatments; P+B 1 and P+B 2 represent PCI-24781 in combination with Bortezomib. The color represents elevated (red) or diminished (green) expression relative to the mean value for the gene and standardized. Rows were ordered to emphasize distinct expression patterns. (b) Real-time PCR for Notch genes confirmed up regulation of expression seen in microarrays in SMS KCNR cells. (A) Notch expression after treatment with PCI-24781 alone and in combination with bortezomib was statistically significantly increased $(\mathrm{P}<0.05)$ in each case except for Notch 3 in SMS-KCNR cells (P=n.s.). Notch 4 was not expressed in any of the cell lines tested. (B) PCI-24781 treatment significantly up regulated expression of the HES1 in both cell lines $(\mathrm{P}<0.05)$. JAG1 and JAG2 were both significantly up regulated by PCI- 24781 in SMS-KCNR cells $(\mathrm{P}<0.01)$ but JAG2 was not significantly changed in SKNBE $(2) \mathrm{C}$ cells. (C) MCYN expression was significantly decreased by treatment with PCI-24781 along and in combination with bortezomib in both cell lines $(\mathrm{P}<0.01)$, while treatment with bortezomib alone did not significantly change MYCN expression $(\mathrm{P}=\mathrm{n} . \mathrm{s}$. $)$. 


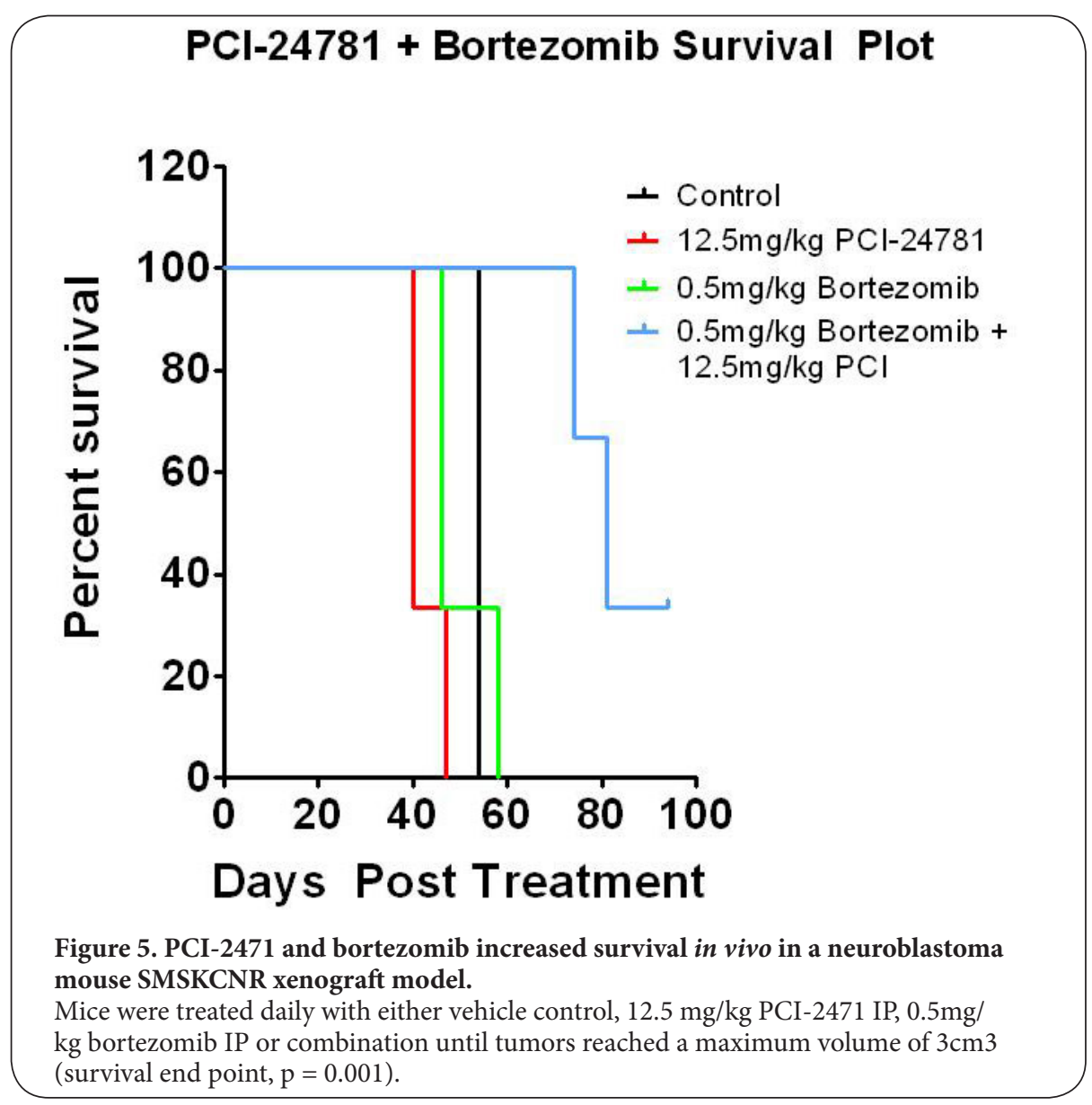

Notch signaling pathway as a significantly up-regulated pathway in our cell lines after treatment with $\mathrm{PCl}-24781$ plus bortezomib. While it is well established that Notch genes function as oncogenes in hematologic malignancies, most notable T-cell acute lymphoblastic leukemia, its specific role remains controversial in solid tumors [44]. Notch signaling has been shown to be oncogenic in breast and colon cancers among others $[45,46]$, but it acts as a tumor suppressor in skin and pancreatic cancer models $[47,48]$.

Two previous studies of HDAC inhibitors in neuroblastoma showed up-regulation of the Notch pathway in response to HDAC inhibitor treatment $[49,50]$. They also showed that this treatment up-regulatedgenes known to be involved in cellular differentiation and growth arrest, leading them to hypothesize that increased Notch signaling was exerting a tumor suppressor effect. On the other hand, more recent studies in neuroblastoma have suggested that increased levels of Notch pathway gene expression correlate with advanced stages and worse clinical outcome, and that blockade of Notch signaling inhibits neuroblastoma growth in vitro and in vivo $[51,52]$. These seemingly contradictory roles of Notch signaling suggest that its effects are likely highly dependent on cellular context and on interactions with other signaling pathways and the tumor microenvironment. This has clearly been shown to be true for many other solid tumors [44]. Additional studies are needed to draw conclusions regarding the role of Notch signaling in neuroblastoma.

In summary, our results show that the HDAC inhibitor PCl24781, when given as a single agent, exhibited significant cytotoxicity and induced apoptosis in a panel of NB cell lines. The combination of $\mathrm{PCl}-24781$ and bortezomib was strongly synergistic in cell lines tested and significantly prolonged survivalin xenograft models compared to either agent alone. This anti-NB activity appears to be ROS-dependent, as shown by prevention of apoptosis and cell death with NAC pretreatment. Enhanced generation of ROS combined with simultaneous inhibition of oxidative stress response genes may represent an important mechanism underlying NB cell death caused by this drug combination. Our finding of significantly decreased expression of NF-KB, one of the primary regulators of oxidative stress response in cells, supports this hypothesis. Finally, we showed that treatment with this combination led to significant up-regulation of many members of the Notch signaling pathway, suggesting a novel pathway of action of these compounds in neuroblastoma that deserves further study. These data suggest that $\mathrm{PCl}-24781$ has a potential for 
use in the treatment of neuroblastoma, both alone and in combination with bortezomib, and future clinical trials in NB patients using these agents should be explored.

\section{Competing interests}

The authors declare that they have no competing interests.

\section{Authors' contributions}

\begin{tabular}{|l|c|c|c|c|c|c|c|c|}
\hline Authors' contributions & GSS & EAC & MAS & SAI & MCF & JAD & SSR & JPB \\
\hline Research concept and design & $\checkmark$ & -- & -- & -- & -- & -- & $\checkmark$ & -- \\
\hline $\begin{array}{l}\text { Collection and/or assembly } \\
\text { of data }\end{array}$ & -- & $\checkmark$ & -- & $\checkmark$ & $\checkmark$ & -- & $\checkmark$ & -- \\
\hline $\begin{array}{l}\text { Data analysis and } \\
\text { interpretation }\end{array}$ & $\checkmark$ & $\checkmark$ & $\checkmark$ & $\checkmark$ & $\checkmark$ & $\checkmark$ & $\checkmark$ & - \\
\hline Writing the article & $\checkmark$ & $\checkmark$ & $\checkmark$ & -- & -- & -- & $\checkmark$ & $\checkmark$ \\
\hline Critical revision of the article & $\checkmark$ & -- & -- & -- & -- & -- & -- & $\checkmark$ \\
\hline Final approval of article & $\checkmark$ & -- & -- & -- & -- & -- & $\checkmark$ & $\checkmark$ \\
\hline Statistical analysis & -- & -- & -- & -- & -- & $\checkmark$ & -- & $\checkmark$ \\
\hline
\end{tabular}

\section{Acknowledgement}

This work was supported by the Friends of Will/Beat NB Foundation, Friends of Will Foundation, Max's Ring of Fire, Owen Moscone Foundation, and Charles and Meryl Witmer Foundation and donations from many families and supporters of neuroblastoma research. We thank Scott Tighe of the Vermont Genetics Network. This publication was made possible by the Vermont Genetics Network through Grant no. P20 RR16462 from INBRE Program of the National Center for Research Resources (NCRR), a component of National Institutes of Health $(\mathrm{NIH})$. Its contents are solely the responsibility of the authors and do not necessarily represent the official views of NCRR and NIH. We thank Dr. SriramBalasubramanian (Pharmacyclics, Inc.) for providing $\mathrm{PCl}-24781$.

\section{Publication history}

EIC: G.J. Peters, VU University Medical Center, Netherlands.

Received: 17-Sep-2013 Revised: 26-Nov-2013

Accepted: 30-Nov-2013 Published: 28-Dec-2013

\section{References}

1. Smith MA, Seibel NL, Altekruse SF, Ries LA, Melbert DL, O'Leary M, Smith $\mathrm{FO}$ and Reaman $\mathrm{GH}$. Outcomes for children and adolescents with cancer: challenges for the twenty-first century. J Clin Oncol. 2010; 28:262534. | Article | PubMed Abstract | PubMed Full Text

2. Maris JM, Hogarty MD, Bagatell R and Cohn SL. Neuroblastoma. Lancet. 2007; 369:2106-20. | Article | PubMed

3. Maris JM. Recent advances in neuroblastoma. N Engl J Med. 2010; 362:2202-11. | Article | PubMed Abstract | PubMed Full Text

4. Dokmanovic $M$, Clarke $C$ and Marks PA. Histone deacetylase inhibitors: overview and perspectives. Mol Cancer Res. 2007; 5:981-9. | Article | PubMed

5. Xu WS, Parmigiani RB and Marks PA. Histone deacetylase inhibitors: molecular mechanisms of action. Oncogene. 2007; 26:5541-52. | Article I PubMed

6. Buchwald $\mathrm{M}$, Kramer $\mathrm{OH}$ and Heinzel T. HDACi--targets beyond chromatin. Cancer Lett. 2009; 280:160-7. | Article | PubMed

7. Richon VM and O'Brien JP. Histone deacetylase inhibitors: a new class of potential therapeutic agents for cancer treatment. Clin Cancer Res. 2002; 8:662-4. | Article | PubMed

8. Minucci $S$ and Pelicci PG. Histone deacetylase inhibitors and the prom- ise of epigenetic (and more) treatments for cancer. Nat Rev Cancer 2006; 6:38-51. | Article | PubMed

9. Sakuma T, Uzawa K, Onda T, Shiiba M, Yokoe H, Shibahara T and Tanzawa $H$. Aberrant expression of histone deacetylase 6 in oral squamous cell carcinoma. Int J Oncol. 2006; 29:117-24. | Article | PubMed

10. Wilson AJ, Byun DS, Popova N, Murray LB, L'Italien K, Sowa Y, Arango D, Velcich A, Augenlicht LH and Mariadason JM. Histone deacetylase 3 (HDAC3) and other class I HDACs regulate colon cell maturation and p21 expression and are deregulated in human colon cancer. $J$ Biol Chem. 2006; 281:13548-58. I Article | PubMed

11. Kim HR, Kim EJ, Yang SH, Jeong ET, Park C, Lee JH, Youn MJ, So HS and Park R. Trichostatin A induces apoptosis in lung cancer cells via simultaneous activation of the death receptor-mediated and mitochondrial pathway? Exp Mol Med. 2006; 38:616-24. I Article I PubMed

12. Qu W, Kang YD, Zhou MS, Fu LL, Hua ZH and Wang LM. Experimental study on inhibitory effects of histone deacetylase inhibitor MS-275 and TSA on bladder cancer cells. Urol Oncol. 2010; 28:648-54. | Article I PubMed

13. Bhalla S, Balasubramanian S, David K, Sirisawad M, Buggy J, Mauro L, Prachand S, Miller R, Gordon LI and Evens AM. PCl-24781 induces caspase and reactive oxygen species-dependent apoptosis through NFkappaB mechanisms and is synergistic with bortezomib in lymphoma cells. Clin Cancer Res. 2009; 15:3354-65. | Article | PubMed Abstract | PubMed Full Text

14. Ungerstedt JS, Sowa Y, Xu WS, Shao Y, Dokmanovic M, Perez G, Ngo L, Holmgren $A$, Jiang $X$ and Marks PA. Role of thioredoxin in the response of normal and transformed cells to histone deacetylase inhibitors. Proc Natl Acad Sci U S A. 2005; 102:673-8. | Article | PubMed Abstract | PubMed Full Text

15. Ruefli AA, Ausserlechner MJ, Bernhard D, Sutton VR, Tainton KM, Kofler $\mathrm{R}$, Smyth MJ and Johnstone RW. The histone deacetylase inhibitor and chemotherapeutic agent suberoylanilide hydroxamic acid (SAHA) induces a cell-death pathway characterized by cleavage of Bid and production of reactive oxygen species. Proc Natl Acad Sci U S A. 2001; 98:10833-8. | Article | PubMed Abstract | PubMed Full Text

16. Xu W, Ngo L, Perez G, Dokmanovic M and Marks PA. Intrinsic apoptotic and thioredoxin pathways in human prostate cancer cell response to histone deacetylase inhibitor. Proc Natl Acad Sci U S A. 2006; 103:15540-5. | Article | PubMed Abstract | PubMed Full Text

17. Oehme I, Deubzer HE, Wegener D, Pickert D, Linke JP, Hero B, KoppSchneider A, Westermann F, Ulrich SM, von Deimling A, Fischer M and Witt O. Histone deacetylase 8 in neuroblastoma tumorigenesis. Clin Cancer Res. 2009; 15:91-9. | Article | PubMed

18. De los Santos M, Zambrano A and Aranda A. Combined effects of retinoic acid and histone deacetylase inhibitors on human neuroblastoma SH-SY5Y cells. Mol Cancer Ther. 2007; 6:1425-32. | Article I PubMed

19. Richon VM, Garcia-Vargas J and Hardwick JS. Development of vorinostat: current applications and future perspectives for cancer therapy. Cancer Lett. 2009; 280:201-10. | Article | PubMed

20. Fouladi M, Park JR, Stewart CF, Gilbertson RJ, Schaiquevich P, Sun J, Reid JM, Ames MM, Speights R, Ingle AM, Zwiebel J, Blaney SM and Adamson PC. Pediatric phase I trial and pharmacokinetic study of vorinostat: a Children's Oncology Group phase I consortium report. J Clin Oncol. 2010; 28:3623-9. | Article | PubMed Abstract | PubMed Full Text

21. Ganesan A, Nolan L, Crabb SJ and Packham G. Epigenetic therapy: histone acetylation, DNA methylation and anti-cancer drug discovery. Curr Cancer Drug Targets. 2009; 9:963-81. I Article I PubMed

22. Rivera-Del Valle N, Gao S, Miller CP, Fulbright J, Gonzales C, Sirisawad M, Steggerda S, Wheler J, Balasubramanian S and Chandra J. PCI-24781, a Novel Hydroxamic Acid HDAC Inhibitor, Exerts Cytotoxicity and Histone Alterations via Caspase-8 and FADD in Leukemia Cells. Int J Cell Biol. 2010; 2010:207420. | Article | PubMed Abstract | PubMed Full Text

23. Yang C, Choy E, Hornicek FJ, Wood KB, Schwab JH, Liu X, Mankin H and Duan Z. Histone deacetylase inhibitor (HDACl) $\mathrm{PCl}-24781$ potentiates cytotoxic effects of doxorubicin in bone sarcoma cells. Cancer Chemother Pharmacol. 2011; 67:439-46. | Article | PubMed

24. Lopez G, Liu J, Ren W, Wei W, Wang S, Lahat G, Zhu QS, Bornmann WG, 
McConkey DJ, Pollock RE and Lev DC. Combining PCI-24781, a novel histone deacetylase inhibitor, with chemotherapy for the treatment of soft tissue sarcoma. Clin Cancer Res. 2009; 15:3472-83. | Article | PubMed

25. Undevia LS, Schilsky R, Loury D, Balasubramanian S, Mani C, Sirisawad M, Buggy JJ, Miller RA and Ratain MJ. Phase I study of the safety, pharmacokinetics $[\mathrm{PK}]$ and pharmacodynamics [PD] of the histone deacetylase inhibitor [HDACi] PCl-24781. J ClinOncol. 2008; 26:14514. | Article

26. Banuelos CA, Banath JP, MacPhail SH, Zhao J, Reitsema T and Olive PL. Radiosensitization by the histone deacetylase inhibitor PCl-24781. Clin Cancer Res. 2007; 13:6816-26. | Article | PubMed

27. Yang C, Choy E, Hornicek FJ, Wood KB, Schwab JH, Liu X, Mankin H and Duan Z. Histone deacetylase inhibitor ( $\mathrm{HDACl}$ ) PCl-24781 potentiates cytotoxic effects of doxorubicin in bone sarcoma cells. Cancer Chemother Pharmacol. 2011; 67:439-46. | Article | PubMed

28. Richardson PG, Barlogie B, Berenson J, Singhal S, Jagannath S, Irwin D, Rajkumar SV, Srkalovic G, Alsina M, Alexanian R, Siegel D, Orlowski RZ, Kuter D, Limentani SA, Lee S, Hideshima T, Esseltine DL, Kauffman M, Adams J, Schenkein DP and Anderson KC. A phase 2 study of bortezomib in relapsed, refractory myeloma. N Engl J Med. 2003; 348:2609-17. | Article | PubMed

29. Perez-Galan P, Roue G, Villamor N, Montserrat E, Campo E and Colomer $D$. The proteasome inhibitor bortezomib induces apoptosis in mantlecell lymphoma through generation of ROS and Noxa activation independent of p53 status. Blood. 2006; 107:257-64. | Article | PubMed

30. Yu C, Rahmani $M$, Dent $P$ and Grant $S$. The hierarchical relationship between MAPK signaling and ROS generation in human leukemia cells undergoing apoptosis in response to the proteasome inhibitor Bortezomib. Exp Cell Res. 2004; 295:555-66. | Article | PubMed

31. Ling $Y H$, Liebes $L$, Zou $Y$ and Perez-Soler R. Reactive oxygen species generation and mitochondrial dysfunction in the apoptotic response to Bortezomib, a novel proteasome inhibitor, in human $\mathrm{H} 460$ nonsmall cell lung cancer cells. J Biol Chem. 2003; 278:33714-23. | Article | PubMed

32. Valentiner U, Haane C, Nehmann $\mathrm{N}$ and Schumacher U. Effects of bortezomib on human neuroblastoma cells in vitro and in a metastatic xenograft model. Anticancer Res. 2009; 29:1219-25. | Article | PubMed

33. Armstrong MB, Schumacher KR, Mody R, Yanik GA, Opipari AW, Jr. and Castle VP. Bortezomib as a therapeutic candidate for neuroblastoma. J Exp Ther Oncol. 2008; 7:135-45. | Article | PubMed

34. Rettig WJ, Spengler BA, Chesa PG, Old LJ and Biedler JL. Coordinate changes in neuronal phenotype and surface antigen expression in human neuroblastoma cell variants. Cancer Res. 1987; 47:1383-9. | Article I PubMed

35. Reynolds CP, Tomayko MM, Donner L, Helson L, Seeger RC, Triche TJ and Brodeur GM. Biological classification of cell lines derived from human extra-cranial neural tumors. Prog Clin Biol Res. 1988; 271:291-306. | Article I PubMed

36. Walton JD, Kattan DR, Thomas SK, Spengler BA, Guo HF, Biedler JL, Cheung NK and Ross RA. Characteristics of stem cells from human neuroblastoma cell lines and in tumors. Neoplasia. 2004; 6:838-45. | Article | PubMed Abstract | PubMed Full Text

37. Irizarry RA, Bolstad BM, Collin F, Cope LM, Hobbs B and Speed TP. Summaries of Affymetrix GeneChip probe level data. Nucleic Acids Res. 2003; 31:e15. | Article | PubMed Abstract | PubMed Full Text

38. Bolstad BM, Irizarry RA, Astrand M and Speed TP. A comparison of normalization methods for high density oligonucleotide array data based on variance and bias. Bioinformatics. 2003; 19:185-93. | Article | PubMed

39. Wilson CL and Miller CJ. Simpleaffy: a BioConductor package for Affymetrix Quality Control and data analysis. Bioinformatics. 2005; 21:3683-5. | Article | PubMed

40. Adimoolam S, Sirisawad M, Chen J, Thiemann P, Ford JM and Buggy JJ. HDAC inhibitor PCI-24781 decreases RAD51 expression and inhibits homologous recombination. Proc Natl Acad Sci U S A. 2007; 104:194827. | Article | PubMed Abstract | PubMed Full Text
41. Zhan Q, Tsai S, Lu Y, Wang C, Kwan Y and Ngai S. RuvBL2 is involved in histone deacetylase inhibitor PCl-24781-induced cell death in SK-N-DZ neuroblastoma cells. PLoS One. 2013; 8:e71663. | Article | PubMed Abstract | PubMed Full Text

42. Bhalla S, Balasubramanian S, David K, Sirisawad M, Buggy J, Mauro L, Prachand S, Miller R, Gordon L and Evens A. The Histone Deacetylase Inhibitor PCl-24781 Induces Caspase and ROS-Dependent Apoptosis Through NF-KB and is Synergistic with Bortezomib in Lymphoma Cells. Clin Cancer Res. 2009; 15:3354-3365. | Article

43. Nawrocki ST, Carew JS, Maclean KH, Courage JF, Huang P, Houghton JA, Cleveland JL, Giles FJ and McConkey DJ. Myc regulates aggresome formation, the induction of Noxa, and apoptosis in response to the combination of bortezomib and SAHA. Blood. 2008; 112:2917-26. | Article | PubMed Abstract | PubMed Full Text

44. Ranganathan P, Weaver KL and Capobianco AJ. Notch signalling in solid tumours: a little bit of everything but not all the time. Nat Rev Cancer. 2011; 11:338-51. | Article | PubMed

45. Reedijk M, Odorcic S, Chang L, Zhang H, Miller N, McCready DR, Lockwood $G$ and Egan SE. High-level coexpression of JAG1 and NOTCH1 is observed in human breast cancer and is associated with poor overall survival. Cancer Res. 2005; 65:8530-7. | Article | PubMed

46. Zhang Y, Li B, Ji ZZ and Zheng PS. Notch1 regulates the growth of human colon cancers. Cancer. 2010; 116:5207-18. | Article | PubMed

47. Hanlon L, Avila JL, Demarest RM, Troutman S, Allen M, Ratti F, Rustgi AK, Stanger BZ, Radtke F, Adsay V, Long F, Capobianco AJ and Kissil JL. Notch1 functions as a tumor suppressor in a model of K-ras-induced pancreatic ductal adenocarcinoma. Cancer Res. 2010; 70:4280-6. | Article | PubMed Abstract | PubMed Full Text

48. Nicolas M, Wolfer A, Raj K, Kummer JA, Mill P, van Noort M, Hui CC, Clevers H, Dotto GP and Radtke F. Notch1 functions as a tumor suppressor in mouse skin. Nat Genet. 2003; 33:416-21. | Article | PubMed

49. Stockhausen MT, Sjolund J, Manetopoulos C and Axelson H. Effects of the histone deacetylase inhibitor valproic acid on Notch signalling in human neuroblastoma cells. Br J Cancer. 2005; 92:751-9. | Article | PubMed Abstract | PubMed Full Text

50. de Ruijter AJ, Meinsma RJ, Bosma P, Kemp S, Caron HN and van Kuilenburg $A B$. Gene expression profiling in response to the histone deacetylase inhibitor BL1521 in neuroblastoma. Exp Cell Res. 2005; 309:451-67. | Article | PubMed

51. Ferrari-Toninelli G, Bonini SA, Uberti D, Buizza L, Bettinsoli P, Poliani PL, Facchetti $F$ and Memo M. Targeting Notch pathway induces growth inhibition and differentiation of neuroblastoma cells. Neuro Oncol. 2010, 12:1231-43. | Article | PubMed Abstract | PubMed Full Text

52. Chang HH, Lee $H$, Hu MK, Tsao PN, Juan HF, Huang MC, Shih YY, Wang BJ, Jeng YM, Chang CL, Huang SF, Tsay YG, Hsieh FJ, Lin KH, Hsu WM and Liao YF. Notch1 expression predicts an unfavorable prognosis and serves as a therapeutic target of patients with neuroblastoma. Clin Cancer Res. 2010; 16:4411-20. | Article | PubMed

\section{Citation:}

Saulnier Sholler G, Currier EA, Dutta A, Slavik MA, Illenye SA, Mendonca MCF, Dragon J, Roberts SS and Bond JP. PCI-24781 (abexinostat), a novel histone deacetylase inhibitor, induces reactive oxygen species-dependent apoptosis and is synergistic with bortezomib in neuroblastoma. J Cancer Ther Res. 2013; 2:21. http://dx.doi.org/10.7243/2049-7962-2-21 